\title{
Perception of hypertensive patients about their non-adherence to the use of medication
}

\author{
Percepção de hipertensos sobre a sua não adesão ao uso de medicamentos \\ Percepción de hipertensos sobre su no adhesión al uso de medicamentos
}

Nadia Sanches Marin¹, Mariana Fonseca dos Santos ${ }^{1}$, André dos Santos Moro²

${ }^{1}$ Medical school student at the University of Marilia, Marília, SP, Brazil.

${ }^{2}$ Cardiologist doctor and medical school faculty teacher at the University of Marilia, Marília, SP, Brazil.

\begin{abstract}
This qualitative study aims to analyze the perception of patients with hypertension on their non-adherence to medication. 13 participants were interviewed, classified as non-adherent. The analysis was performed using the technique of thematic content analysis. Data points to contradictions in the approach of what is being adherent or not, the difficulty of adhering to the use of medication due to lifestyle habits, that forgetting is understood as a justification for non-compliance, and reinforces factors that hinder such practice, such as the use of many drugs, the presence of signs and symptoms and changes in daily routine. With complex conditions that involve non-adherence to treatment and the current context of the predominance of chronic diseases, it is essential to invest in innovative strategies of care for such people.
\end{abstract}

\section{DESCRIPTORS}

Patient Compliance; Hypertension; Use of Medication. 


\section{INTRODUCTION}

The aging of the population, concomitant with the increase of non-transmissible chronic diseases, makes the health system face new problems marked by chronicity and complexity, with the need for differentiated ways to manage care. In this context, the use of medication is a very common condition among the general population, which has generated serious problems, considering the high prevalence of inappropriate use, whether due to prescription, the dispensing or use of them.

The WHO estimates that more than $50 \%$ of medicines are prescribed or dispensed improperly and that $50 \%$ of patients taking medication incorrectly leading to high morbidity and mortality. The most common types of irrational drug use are related to people using polypharmacy, the inappropriate use of antibiotics and injectable medication, self-medication and the prescription in disagreement with clinical guidelines ${ }^{(1)}$.

The rational use of medicines include "appropriate prescribing; the opportune availability and at affordable prices; dispensation in adequate conditions; and the use at the indicated doses in intervals and in the period of time indicated, of effective, safe and quality medicines" (2).

In this context, the non-adherence of users seems to be a frequent occurrencethat is difficult to control because of the existence of multiple factors that may be related to the individuals who must use them correctly to get the desired effect. Adherence, from the etymological point of view, from Latin adhaesione, means junction, union, approval, consent, expression of solidarity, support; presupposes relationship and bond ${ }^{(3)}$.

In clinical practice, currently the following understanding of adherence is proposed "as a dynamic and multifactorial process that includes physical, psychological, social, cultural and behavioral aspects, which requires shared decision-making and co-responsibility between the person living with the disease, the health team and the social network". It is understood to be a multifactorial process, structured on the relationship between those who take care and those who receive care and involves patience, perseverance and the frequency ${ }^{(4)}$.

Added to this understanding the principle of autonomy, because treatment requires patient compliance with the recommendations issued, implying the performance of an active and participatory role in their health care. It also considered the need for a good professional/patient relationship for satisfactory adherence ${ }^{(5)}$.

The term "adhesion" when applied to the use of medication relates to its use according to the prescription. Adherence to use of medications is related to several factors, highlighting the satisfactory level of information and the interest of the patient to engage in the therapeutic plan.

Referring to adherence to prescribed medications, patients with chronic diseases are those which have lower rates ${ }^{(6)}$.Among chronic diseases, cardiovascular are the leading cause of death, besides generating disabilities, dependency and loss of autonomy, they represent a heavy economic and social cost. Among cardiovascular diseases,
Hypertension (HTN) is the most prevalent and increases progressively with age ${ }^{(7)}$.

One study showed that none of the hypertensive patients studied showed optimal levels of adhesion, while the majority was classified as mild non adherents ${ }^{(8)}$.

A study revealed that none of the appraised hypertensive individual presented ideal adhesion, although most has been classified as light non-adherent ${ }^{(8)}$. In comparative analysis of the adhesion to the medical treatment among urban and rural population it was found that more than $60 \%$ of the interviewees were considered as non- adherent and that non adhesion is related to the age group, to the low income, to the alcoholism and the way of connecting with the health services. However there was no association with the place of residence ${ }^{(9)}$.

It is considered as non-adherence to the treatment of HTN when the use of the medicine does not coincide partially or totally with the therapeutic plan and, when it refers to the bearer of HTN, it is considered as an invisible epidemic, once its prevalence varies according to the method employed and it is higher in developing countries, as it is the case of Brazil (10).

In his quotidian the bearer of the chronic disease assumes the role of protagonist in the control of the disease, because he/she deals with it and takes the responsibility for the follow up and administration of the prescribed therapeutics and making decisions in relation to the disease and treatment ${ }^{(11)}$.

In this context it is necessary to point out that the adherence of the hypertensive individual to the treatment demands change of behavior and requires great effort, because it involves breaking the habits built throughout life. The difficulties in the changes of habits are associated to the conditions of the modern life with its multiple demands ${ }^{(12)}$.

Taking it into consideration, it is up to the health professionals to support the hypertensive individual in the perspective of the extension of the care, so that it is understood in its individuality, through the approach centered in the patient and in the interactivity. Those actions contribute so that the HTN individual becomes responsible for his/ her own health ${ }^{(13)}$.

It is considered as non-adherence to treatment of HTN when use of the medicine does not match partially or completely with the treatment plan and, when referring to the sufferers of HTN, comes to be regarded as an invisible epidemic, but its prevalence varies with the method used and is higher in developing countries, such as Brazil ${ }^{(8)}$.

When considering the field of healthcare has a complex body of knowledge guided by attitudes toward care, knowledge of the user's perspective is an important contribution in addressing the increase in the use of medications. Therefore, studies of qualitative approach are important since they allow increasing the patient's role as a social being endowed with knowledge, interests, values and expectations that produce different senses and meanings in relation to management of their disease ${ }^{(14)}$.

Thus, although the increase in the use of medications in hypertensive patients is a subject explored in the literature, 
especially when referring to the reasons for non-adherence, many questions still remain with regard to their understanding, which is an important aspect when it comes to the adoption of strategies aimed at better adherence from them. In the present study it is proposed to analyze the perception of patients with HTN about non-adherence to the use of medication.

\section{METHOD}

Descriptive qualitative study to enable the possibility of a closer approach to the object of research and understanding of the experiences as a whole ${ }^{(15)}$.Conducted with hypertensive patients followed in the out-patient clinics of cardiology atthe State University of São Paulo. This clinic serves approximately 180 patients a month forwarded from primary care units of health in the municipality, forwarded by theappointmentcenter. The majority of patients treated have HTN.

Data was collected in the Cardiology outpatient clinic, upon arrival. Initially the patient was called into a room or office, was introduced to the researchers and questioned about the proper use of medication, as proposed by Haynes et al: "Many people have some kind of problem in taking their medicines. In the last 30 days Mr. (Mrs.) have you struggled to take your meds?" whose affirmative answer indicates that the individual is non-adherent ${ }^{(16)}$. In cases where the patient was classified as non-adherent they were invited to respond to questions about the significance of taking medicines and non-adherence to them. Thirteen participants were interviewed and the interviews were recorded and transcribed in full for later analysis. Data collection was terminated when it was realized that the data obtained was becoming repetitive.

For data analysis, we opted for the thematic analysis technique, due to its suitability for studies of opinion, attitudes, values and trends. In order to operationalize the referred technique the author establishes three stages: 1 . pre-analysis that consists of the organization of the data, with the purpose to operationalize and systematize the first ideas that will orient the structure of development of the successive analytic operations; 2 . exploration of the material that aims at essentially to accomplish the code operations and definition of categories and it consists of a procedure of systematic conversion of the collected data in way to group them in units that describe the most pertinent characteristics of the content; 3 . phase of treatment and interpretation of the obtained data is when a presentation of the results, proposition of inferences and interpretations referring to the foreseen objectives or unexpected discoveries take place ${ }^{(17)}$.

Thus, after the transcription of the interviews by the authors, the reading of each interview was accomplished, followed by the organization of the material to highlight the key points of the text. As a result the material was subjected to a thorough study, as supported by referenced work, aiming to separate the recorded units, in other words, encoding raw data from the text, changing by cropping the text, gathering and classification, to allow a representation of the content by the development of three categories of analysis. In the stage of processing the results, relationships and deductions supported by reflection and theoretical foundation were established, which enabled comparisons and considerations of the data found ${ }^{(15)}$.

For data collection, the project had the approval of those responsible for the outpatient clinic of Cardiology and with the approval of the Ethics Committee for Research in Humans of the University. Patients with HTN were informed about the purpose of the study and signed a consent form. In order to preserve anonymity, participants were identified with the letter " $E$ " followed by the numeric code concerning the order of the interview.

\section{RESULTS AND DISCUSSION}

It is important to note that although the approach to the participants has been in a private room and researchers have presentedtheir research objectives to them, before the first question that classified them as adherent and non-adherent, as a condition for continuing in the study, participants had great difficulty recognizing themselves as non-adherent. Studies show a large proportion of hypertensive patients who make inadequate use of medication, as an example it is quoted a study that examined the adherence of elderly people with hypertension to medication and non-medication in the state capital of Paraiba, where more than half of them were classified as non-adherent ${ }^{(18-19)}$.

The age range of participants was 25-83 years, three of them illiterate, two with incomplete primary education and five with complete primary school, two with complete high school and pursuing higher education. Data shows that among the interviewees there was great variation in the socio-demographic aspects. However, even considering that studies show positive association between adherence and factors such as age, genre, economic conditions and life habits, it is certain that the adherence to the medicine use is low in all the situations.

When trying to understand the perception of hypertensive patients about their non adherence, it is evident that ignorance of the importance of correct use still permeates the lack of adherence. However, complex factors inherent to the individual himself contribute to this occurrence, allowing the development of the categories of analysis discussed below.

\section{THE CONTRADICTION PERMEATING THE PERCEPTION OF NON-ADHERENCE.}

In the course of the interview, despite having been classified as non-adherent, participants deny non-adherence and recognize the importance of correct treatment, following a process full of contradictions, returning to claim non-adherence, sometimes in a move of guilt and concern, sometimes with the belief that they were not being harmed by misuse, as shown in the quote below.

"I think it is necessary to use (...) for me is a holy me-
dicine (...) when I go to the doctor there is this pro-
blem, I think he will ask for an examination, asks if 
I am fasting, so we can do a blood test, then I forget, but usually I do not forget (...) my wife also takes and she reminds me. Only if I travel, if I travel I can forget to take it. Today I feel nothing, but the pressure is bigh. Then I feel irresponsible because I feel I should have taken (...) But I thought the doctor could suddenly ask for a blood test, those who make you fasting, and then I would solve the problem. I'm sure I will not get worse, I'm not feeling anything" (E1).

"It's a complicated situation (talking about forgetting), is a thing of the moment, the next day you end up getting kinda bad, kinda sad, because you did not took the medicine ..." (E12)

In view of such considerations and when referring to the contradiction it is important to mention that there are different interpretations on it, being the main of them the perspective of the formal logic and of the dialectic. The contradiction in the formal logic is understood as "absolute and appropriate reflections of the objective reality", while for the dialectic, the contradiction denotes the interpenetration of opposites in the unit, in other words, the possibility of separation of the opposites does not exist ${ }^{(20, p .59)}$. For two characteristics to be opposite, they should have something in common, remaining actively interconnected inside of a given phenomenon or object. This way it is composed an important movement for the changes to happen, once a system that goes by the "units of opposites" it is being proposed to something that was not ${ }^{(20)}$. It is in this perspective that the contradiction expressed by the interviewees is understood, because it reveals the moment of transition between do not have the disease and to become bearer of HTN is and it is expressed through the conflict lived when finding himself non adherent to the treatment.

In the quotes of speech below, there is a clear recognition of the importance of the use of medications for maintenance of health conditions, the statement that is of adequate usage, followed by the information that it is forgotten. Also, mentioning the effects of social and cultural habits.

"It means a lot (taking the medicine), because it con-
trols my health, it feels good, because sometimes you do
not take the medicine and do not feel good so I control
it just right there. This is my daily life controlled with
medication. It's hard for me to forget, is easier after
lunch (...) sometimes is the habit of people. When I'm
having lunch, I drink soda and I forget to take the
medicine, only then I end up forgetting... "E2

Even considering the use of the medicine as central to life, the participant claims that he has not yet acquired the habit of taking the medicine at the time indicated. Adherence to the use of medications seems to involve socially desirable behavior, which is strongly related to collective habits that influence individual choices ${ }^{(12)}$. Therefore it appears that "taking soda" is a condition more socially accepted and expected than taking a medicine with food.

It is added that several Psychosocial factors such as lack of motivation, social influence, beliefs and feelings of self-efficacy, influence changes in our lifestyle in a positive or negative way, which is necessary for the hypertensive person that takes medication. Behavior change requires great effort, because it requires breaking with ingrained habits that were socially and culturally acquired throughout life. The difficulties in changing habits associate themselves also to daily conditions of modern life with its multiple demands ${ }^{(21)}$.

It is important to add that a chronic patient, when experiencing the illness process he/she starts to acquire knowledge and experience on the disease according to his/her internal abilities to deal with it in different situations. Thus, to move forward in the health care, it is necessary to involve the individual in the shared decision making process, helping him/her to recognize their individual needs, goals and beliefs ${ }^{(22)}$.

\section{FORGETFULNESS AS A WAY TO JUSTIFY NON ADHERENCE FOLLOWED BY FEELINGS OF DISAPPOINTMENT}

To "forget", or "just forget" as said by the interviewee manifests as a deliverance from liability, even if in eventually it ends up causing the fact that medication is not taken.

"The right way would be to take it correctly, but as
we forget (...). I forget, simply forget. Sometimes I
drink one or two at the bar (laughs) I get home and
end up forgetting the one in the morning (...) When I
remember I speak nonsense and take it (...) when I do
not remember..." (E4)
Usually I get up, do things for my son and rest some
more, then I'll get up running and go to work and
forget. I usually take it when I arrive at work, today
for example I have not taken it yet (...) you get there
and you are so run over with work that you end up
forgetting, then you remember and say "I'll take it"
but then you end up forgetting to go get it."(E7)

Thus it vindicates the understanding that promoting health is to "maximize the capacity that each individual has to tolerate, confront and correct those risks or betrayals that inevitably are part of our history"(23).It adds up that understanding the intertwining of factors that shape health practices involves complex and comprehensive elements including the concepts of interdisciplinarity, intersectionality, equity, empowerment of individuals and institutions involved and quality of life ${ }^{(24)}$. From the perspective of health promotion that involves changing habits, it is argued that its construction takes place in everyday life, including the environment as a living area, dynamic and reflective of economic, historical and cultural processes ${ }^{(19)}$.

\section{HIGHILIGHT FACTORS THAT INTERFERE WITH ADHERENCE.}

Even though admittedly is the person who decides whether to adhere to treatment and will only do it from the moment they accept how important it is to them and incorporate it in their life habits, it was noted that they face problems that can be solved easily and need considering and monitoring by health professionals, in the logic of public health supervision, involving ongoing monitoring, trust and accountability. 
"I stopped taking a medication because of my stomach, I take many pills, 11 per day (...) Not that I did not realize, is that when I realized that I was taking too much medicine I removed atenolol, but I think there was not time for it to take effect." (E5)

"(taking the medicine correctly) means tranquility (...) because I do not like to take these medications but it is necessary, am I right! Because I feel very sleepy with this medication, much weakness, they were messing with my work, so I decided to stop for a few days to see if I got better, sleep has improved, but arterial pressure rose so I went back...” (E10)

"The thing is at the end of the week I like to have a beer, and I think you cannot mix, so, I don't have the medicine. This is the only thing that interferes with me taking the medication (...) I feel nothing, sometimes I get a little weak, weakness, but I do not feel bad... "(E9)

Another aspect reported by them is the difficulty of taking the medicine properly when any change occurs in their daily routine, as shown in following quote:

\section{"If I forget to take in the morning, I leave to take only the next day, the days that I forget, are usually the days I'm not at home ..." (E12)}

Faced with such comments, we believe in the importance of changes in the strategies of health care for people with long term medication use. Although the group actions and health education has relevance in this process, it is necessary to improve support and ongoing support to these people, so that there is a systematic individualized monitoring and there is a recognition of their real needs. In this complex movement, individual and collective actions must go beyond health care.

Understanding that the adherence to the medical treatment for individuals with chronic diseases demands the change of medicines, it is necessary to incorporate in its daily practice, adaptation mechanisms that facilitate the treatment, maintain an effective communication with health professio- nals, simplification of the therapeutic regime, associate the use of medicines to the daily activities among other actions that might contribute to the incorporation of that use ${ }^{(25)}$.

Furthermore, we must recognize the importance of the role of the hypertensive patient in the process of adhering to treatment because in reviewing the literature on adherence/non-adherence to treatment of people with chronic diseases, it was found that professionals consider the patientcompliant with the health service limiting the possibility of active participation ${ }^{(26)}$. It is worth adding to this that they often present inaccurate notions about the disease ${ }^{(27)}$.

\section{CONCLUSIONS}

In an effort to broaden the understanding of patients with hypertension on non-adherence to medications, it is highlighted the importance of performance in health looking at the thoughts and acts of each individual, involving their cultural and social context, since the adherence to use of medications goes far beyond their knowledge about the same and of the recognition of the importance of properly following the prescription. It involves working together with individuals to change habits that were built throughout life. Therefore, healthcare professionals should go beyond providing information, especially if in that process the knowledge, beliefs, values and difficulties of each participant are not valued. Thereby, collective and individual actions intertwine, with a view to changing habits.

This study reinforces that in the face of complex conditions involving non adherence to treatment and the current context of the prevalence of chronic diseases such as hypertension, it is essential to invest in innovative strategies for the care of such people. In this context, although the clinics of each specialty field should engage in a process of more extended care, there should be priority investment in primary care so that it is possible to maintain a professional/ user bond, and with other levels of care, so that healthcare is established in networks.

\section{RESUMO}

Estudo qualitativo que se propõe a analisar a percepção do portador de hipertensão arterial sobre a sua não adesão ao tratamento medicamentoso. Foram entrevistados treze participantes classificados como não aderente. A analise foi realizada pela técnica de analise de conteúdo modalidade temática. Os dados apontam para contradições na abordagem sobre o que é ser ou não aderente, a dificuldade de aderir ao uso dos medicamentos devido ao hábito de vida, que o esquecimento é compreendido como uma justificativa para a não adesão, além de reforçarem fatores que dificultam tal prática, como o uso de muitos medicamentos, presença de sinais e sintomas e mudanças na rotina diária. As complexas condições que envolvem a não adesão ao tratamento e ao o atual contexto de predomínio de doenças crônicas, é primordial que se invista em estratégias inovadoras de cuidado a tais pessoas.

\section{DESCRITORES}

Cooperação do Paciente; Hipertensão; Uso de Medicamentos.

\section{RESUMEN}

Estudio cualitativo que se propone a analizar la percepción del portador de hipertensión arterial sobre su no adhesión al tratamiento medicamentoso. Fueron entrevistados trece participantes clasificados como no adherente. El análisis fue realizado por la técnica de análisis de contenido modalidad temática. Los datos apuntan para contradicciones en el abordaje sobre lo que es ser o no adherente, la dificultad de adherir al uso de los medicamentos debido al hábito de vida, que el olvido se comprende como una justificativa para la no adhesión, además de reforzar factores que dificultan tal práctica, como el uso de muchos medicamentos, presencia de señales y síntomas y mudanzas en la rutina diaria. Las complejas condiciones que involucran la no adhesión al tratamiento y al actual contexto de predominio de enfermedades crónicas, es primordial que se invierta en estrategias innovadoras de cuidado a tales personas. 


\section{DESCRIPTORES}

Cooperación del Paciente; Hipertensión; Utilización de Medicamentos.

\section{REFERENCES}

1. WHO. The safety of medicines in public health programmes: pharmacovigilance na essential tool. Geneva: WHO; 2006.

2. Brasil. Ministério da Saúde. Portaria no 3.916, de 30 de outubro de 1998. Aprova a Política Nacional de Medicamentos [online]. Diário Oficial da União, Brasília (DF);01 out 1998. [acessado 2007 nov 21]. Disponível em: http://bvsms.saude.gov.br/bvs/saudelegis/gm/1998/ prt3916_30_10_1998.html

3. Brasil. Ministério da Saúde (MS). Secretaria de Vigilância em Saúde. Programa Nacional de DST e Aids. Diretrizes para o fortalecimento das ações de adesão ao tratamento de pessoas que vivem com HIV e AIDS. Brasília: MS; 2007.

4. Silveira LMC, Ribeiro VMB. Grupo de adesão ao tratamento: espaço de "ensinagem" para profissionais de saúde e pacientes. Interface comun. saúde educ. 2005; 9(16):91-104.

5. Caraciolo JMM, Shimma E, coordenadoras. Secretaria de Estado da Saúde. Coordenadoria de Controle de Doenças. Programa Estadual DST/Aids-SP. Adesão da teoria à prática: experiências bem sucedidas no estado de São Paulo. São Paulo: Centro de Referência e Treinamento DST/Aids, 2007; 289p.

6. National Collaborating Centre for Primary Care. Medicines Adherence: involving patients in decisions about prescribed medicines and supporting adherence. Full Guideline. [internet]. 2009 [acesso em 14 dez 2013]; Disponível em: https://www.nice.org.uk/ guidance/cg76

7. Brasil. Ministério da Saúde. Secretaria de Atenção à Saúde. Departamento de Atenção Básica. Hipertensão arterial sistêmica. Brasília: Ministério da Saúde; 2006. 58 p. (Cadernos de Atenção Básica; 15).

8. Vitor AF, Monteiro FPM, Morais HCC, Vasconcelos JDP, Lopes MVO, Araújo TL. Perfil das condições de seguimento terapêutico em portadores de hipertensão arterial. Esc. Anna Nery Rev. Enferm. 2011; 15(2):251-260.

9. Magnabosco P, Teraoka EC, Oliveira TEM, Felipe EAF, Freitas DF, Marchi-Alves LM. Análise comparativa da não adesão ao tratamento medicamentoso da hipertensão arterial sistêmica em população urbana e rural. Rev. Latinoam Enferm. 2015; 23(1):20-27.

10. Borges JWP, Moreira TMM, Rodrigues MTP, Souza ACC, Silva DB. Validação de conteúdo das dimensões constitutivas da não adesão ao tratamento da hipertensão arterial. Rev. Esc. Enferm. USP. 2013;47(5):1076-1082.

11. Mantovani MF, Mendes FRP. A condição crônica de saúde: do diagnóstico a gestão cotidiana da situação. In: Trentini, M.; Paim, L.; Guerreiro, D, editoras. Condições crônicas e cuidados inovadores em saúde. São Paulo: Atheneu, 2014. p. 11-26.

12. Reiners AAO, Azevedo RCS, Vieira MA. Produção bibliográfica sobre adesão/não adesão de pessoas ao tratamento de saúde. Ciênc Saúde Coletiva. 2008; 13(Sup 2):2299-306.

13. Raymundo CAN, Pierin AMG. Adherence to anti-hypertensive treatment within a chronic disease management program: a longitudinal, retrospective study. Rev Esc Enferm USP. 2014; (5):811-9.

14. Leite SN, Vasconcelos MPC. Adesão à terapêutica medicamentosa: elementos para a discussão de conceitos e pressupostos adotados na literatura. Ciênc. saúde coletiva. 2003; 8(3):775-782.

15. Minayo MCS. O desafio do conhecimento: pesquisa qualitativa em saúde. 13ª ed. São Paulo: Hucitec; 2013.

16. Freitas JGA, Nielson SEO, Porto CC. Adesão ao tratamento farmacológico em idosos hipertensos: uma revisão integrativa da literatura. Rev soc Bras Clin Med. 2015;13(1):75-84.

17. Bardin L. Análise de conteúdo. 10. ed. São Paulo: Edições 70, 2011.

18. Dourado CS, Macedo-Costa KNF, Oliveira JS, Leadebal ODCP, Silva GRF. Adesão ao tratamento de idosos com hipertensão em uma unidade básica de saúde de João Pessoa, Estado da Paraíba. Acta sci., Health sci. 2011; 33(1):9-17.

19. Chor D. Saúde pública e mudanças de comportamento: uma questão contemporânea. Cad. saúde pública.1999; 15(2):423-425.

20. Marquit E. Contradições na dialética e na lógica formal. Princípios. 1997; 43(3):58-68.

21. Caponi S. A saúde como abertura ao risco. In: Czeresnia D, Freitas CM, organizadores. Promoção da saúde: conceitos, reflexões, tendências. Rio de Janeiro: Editora Fiocruz; 2003. p. 55-78.

22. Luz EL, Basto ML. The opinion of patients with COPD: the process of becoming chronically ill. Ciênc Saúde Colet [Internet]. 2013. [cited 2013 Ago 22];18(8): 2221-28. Available from: http://www.scielo.br/pdf/csc/v18n8/06.pdf

23. Andrade LOM. A saúde e o dilema da intersetorialidade. São Paulo: Hucitec, 2006.

24. Akerman M. Saúde e desenvolvimento local: princípios, conceitos, práticas e cooperação técnica. São Paulo: Hucitec, 2005.

25. Dias AM, Cunha M, Santos A, Neves A, Pinto A, Silva A, Castro S. Adesão ao regime Terapêutico na Doença Crónica: Revisão da Literatura. Millenium. 2011; 40:201 21

26. Reiners AAO, Nogueira MS. Conscientização do usuário hipertenso para a adesão ao tratamento. Rev. latinoam. enferm.2009; 17(1):5965.

27. Leao e Silva LO, Soares MM, Oliveira MA, Rodrigues SM, Machado CJ, Dias CA. "Tô sentindo nada": percepções de pacientes idosos sobre o tratamento da hipertensão arterial sistêmica. Physis (Rio J.). 2013; 23(1):227-242. 